\title{
Study on the Stability and Compatibility of the Cosmetic Products with Lavandula angustifolia Oil Kept in PPH Polypropylene Homopolymer Plastic Containers
}

\author{
MIHAELA BOGDAN ${ }^{1}$, LAURA ENDRES ${ }^{1}$, BIANCA PASCA ${ }^{1}$, DELIA MIRELA TIT ${ }^{1 *}$, DIANA UIVAROSAN ${ }^{1}$, DANA MARIA COPOLOVICl ${ }^{2,3 *}$, \\ LOTFI ALEYA ${ }^{4}$, SIMONA BUNGAU ${ }^{1}$ \\ ${ }^{1}$ University of Oradea, Faculty of Medicine and Pharmacy, 29 N. Jiga Str., 410028, Oradea, Romania \\ ${ }^{2}$ Aurel Vlaicu University, Faculty of Food Engineering, Tourism and Environmental Protection, 77 Revolutiei Blvd., 310130, Arad, \\ Romania \\ ${ }^{3}$ Institute for Research, Development and Innovation in Technical and Natural Sciences, Romania, 2 Elena Dragoi Str.,Arad, \\ 310330, Romania \\ ${ }^{4}$ Laboratoire Chrono-environnement, Universite de Franche-Comte, Besancon, F-25030, France
}

The products used in cosmetic formulations are continuously diversifying as a result of researches in the field, which combine the healing and prevention of many skin conditions with the use of natural products such as vegetable extracts and essential oils. Testing the stability and compatibility of new or modified cosmetics is required to ensure that quality standards are met when stored in properconditions for functionality and aesthetics, to preserve their chemical, microbiological and physical properties. In this study, the stability and compatibility of a new cosmetic product containing lavender essential oil in plastic container-plastic jar $100 \mathrm{~mL}$ PPH Polypropylene homopolymer (Moplen HP648T) is tested against the glass receptacle used as a control. The monitored parameters were organoleptic characteristics (appearance, color, fragrance), physicochemical ( $\mathrm{pH}$, density), under controlled temperature conditions, and the microbiological ones. The results of this study showed that the tested cosmetic product is compatible with the plastic container; data obtained were comparable with the organoleptic and physicochemical test results obtained in the case of the control sample stored at room conditions.

Keywords: stability, compatibility, cosmetics, Lavandula angustifolia oil, plastic cotainers

The curative effect of essential oils on mind, body, and spirithas demonstrated its importance for centuries. These very powerful organic chemicals in plants, named aroma molecules, have the property of removing viruses, bacteria and fungi from surrounding areas [1,2]. The popularity of aromatherapy is growing, cosmetics brands including essential oils on a large scale in their products. Consumers that do not mind paying more for natural products determined new formulations and innovations in the cosmetics industry. Products used in aromatherapy quickly gained popularity in the cosmetics market that includes perfumes, emollients and body creams [2].

Lavandula angustifolia oil is the volatile oil obtained from the flowers of the Lavender, Lavandula angustifolia, Labiatae [3]. Although the mechanisms of action of lavender oil are not entirely known, it has antifungal and antibacterial properties on many differentbacteria species, especially when antibiotics have no effect [4]. The use of lavender oil in aromatherapy for the treatment of stress, headaches, abrasions, skin problems, painful muscles, primary dysmenorrhea, burns and stimulation of the immune system is well documented [5-8].

Among the properties of lavender essential oil in cosmetics we can list: relieves dry skin, detoxifies pores and stimulates cell regeneration [2,9]. In order to preserve its properties in cosmetic products it has to be incorporated into well-studied formulations together with compatible components so that the final cosmetic product fulfills the quality standards when stored in proper conditions for functionality and aesthetics, to preserve their chemical, microbiological and physical properties. The stability of the final product is directly influenced by the primary packaging, due to the many interactions that may occur between the product and the packaging on the one hand (corrosion, chemical reactions, migration adsorption of product components into the container) and between the product, the packaging and the external environment, on the other hand (the effectiveness of a container to protect the contents from the effects of water and/or atmospheric oxygen vapour and to ensure the retention of volatile product and water components is represented by the barrier properties of the container) [10].

In this study, the stability and compatibility of a new cosmetic product containing lavender essential oil was tested and stored in a $100 \mathrm{~mL}$ volume PPH plastic homopolymer (Moplen HP648T) plastic container. PPH is the result of the specific polymerization of propane using a Ziegler-Natta catalyst, by injection [11-13]. It appears in granular form, stabilized under normal conditions, having a natural color and very good chemical resistance to various chemical agents, basic or acidic. The material is used for the manufacture of parts of household appliances, technical products, medical devices, and packaging containers used in various industrial branches: food, textile, electrotechnics, etc. Our results were compared with those obtained for the same product, stored in a glass container and used as control.

\section{Experimental part \\ Material and method}

Tested product was hand and body cream, formulated and prepared from $100 \%$ natural ingredients (table 1) in Viridis Cosmetics laboratories, by pharmacist Mihaela Bogdan.

The distilled water was obtained in the private laboratories with a GFL / 205458 type 2008 distiller. The raw materials were purchased from Mayam Elemental (Romania), all of them were accompanied by a quality 
Table 1

PREPARATION FORM, QUALITATIVE AND QUANTITATIVE COMPOSITION OF TESTED COSMETIC CREAM

\begin{tabular}{|c|c|c|c|}
\hline $\mathrm{A} / \mathrm{A}$ & TRADE NAME & $\underset{\%}{\mathbf{W} / \mathbf{W}}$ & PROCEDURE \\
\hline & & & Phase A \\
\hline 1. & $\begin{array}{l}\text { Macadamia integrifolia } \\
\text { seed oil }\end{array}$ & 10.00 & \multirow{4}{*}{$\begin{array}{l}\text { Heat substance number } 1-4 \text { to } \mathrm{t}=70^{\circ} \mathrm{C} \text { into the main preparation vessel } \\
\text { under moderate stirring. }\end{array}$} \\
\hline 2. & $\begin{array}{l}\text { Butyrospermum parkii } \\
\text { butter }\end{array}$ & 5.00 & \\
\hline 3. & Coco-caprylate & 5.00 & \\
\hline 4. & Sorbitan olivate & 6.00 & \\
\hline \multicolumn{4}{|r|}{ Phase B } \\
\hline 5. & Aqua destillata & 65.00 & \multirow{3}{*}{$\begin{array}{l}\text { Bring substance number } 5-7 \text { into a secondary vessel and heat to } t=70^{\circ} \mathrm{C} \text {, } \\
\text { under moderate stirring. } \\
\text { At } \mathrm{t}=70{ }^{\circ} \mathrm{C} \text {, add phase } \mathrm{B} \text { into the main preparation vessel, under } \\
\text { homogenisation and vigorous stirring. Maintain the homogenisation and } \\
\text { vigorous stirring for } 5-10 \mathrm{~min} \text {, without cooling, until a homogenous } \\
\text { emulsion is obtained. }\end{array}$} \\
\hline 6. & Glycerin & 5.00 & \\
\hline 7. & Urea & 3.00 & \\
\hline \multicolumn{4}{|r|}{ Phase C } \\
\hline 8. & Tocopherol & 0.50 & \multirow{4}{*}{$\begin{array}{l}\text { Cool down the obtained emulsion to } \mathrm{t}=30^{\circ} \mathrm{C} \text {, while moderate stirring. } \\
\text { At } \mathrm{t}=32^{\circ} \mathrm{C} \text { add substance number } 8-11 \text { into the main preparation vessel, } \\
\text { under homogenization, vigorous stirring and cooling. } \\
\text { Maintain the homogenization and vigorous stirring of the bulk product for } 5 \\
\text { minutes, while cooling. } \\
\text { Check pH, which has to be } 6.0 \text {. Bring bulk product sample to original } \\
\text { packaging, according protocol. }\end{array}$} \\
\hline 9. & $\begin{array}{l}\text { Phenoxyethanol, } \\
\text { ethylhehylglycerin }\end{array}$ & 1.00 & \\
\hline 10. & Lavandula angustifolia oil & 0.50 & \\
\hline 11. & Pelargonium roseum oil & 0.30 & \\
\hline & TOTAL & 100.000 & \\
\hline
\end{tabular}

certificate. The preservative used (Phenoxyethanol, Ethylhexylglycerin) was provided by Gracefruit LTD (England). All materials used in the formula have been applied in accordance with their purpose, in a permitted quantity and do not constitute a threat to human health. The raw materials used to formulate this product are all well-known ingredients with a long history of safe use. The product obtained is characterized by the parameters described in table 2.

Table 2

CHARACTERISTICS OF THE TESTED PRODUCT

\begin{tabular}{|c|l|}
\hline Parameter & \multicolumn{1}{|c|}{ Description } \\
\hline Aspect & Emulsion/Homogeneous cream \\
\hline Color & White / white-yellowish, characteristic \\
\hline Fragrance & Characteristic for used ingredients/ Floral scent \\
\hline pH (at $\left.25^{\circ} \mathrm{C}\right)$ & $5-6$ \\
\hline Packaging & Original packaging-jar with cap $100 \mathrm{~mL}$ (PP, PS) \\
\hline
\end{tabular}

Depending on the product category (emulsion / homogenous cream), we have chosen the most appropriate testing methodology for this type of product. We considered the evaluation of critical aesthetic properties such as organoleptic properties (appearance, color, perfume), but also physicochemical parameters (density, $\mathrm{pH}$, temperature cycle test (5-40 three series), temperature variations $140^{\circ} \mathrm{C}$, II $5^{\circ} \mathrm{C}$ and a control sample at room temperature RT (temperature 0 being $25^{\circ} \mathrm{C}$ ).

The purpose of the test was to ensure stability, physical integrity, microbiological stability and compatibility of the contents with the original packaging of our cosmetic product under appropriate storage, transport and use conditions. Thus, after determining the stability and compatibility with the container, an assessment of the antimicrobial preservative of the cosmetic product was also carried out; the evaluation was done by using a challenge test according to SR EN ISO 1190: 2012 [14]. The assay implies the contamination of the formulation with a determined inoculum with known density and the monitorization of viability of test microorganisms at pre- established time intervals (7, 14 and 28 days) for each strain - $20 \mathrm{~g}$ of the test formulation $0.2 \mathrm{~mL}$ of calibrated

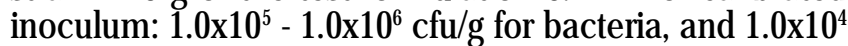
- 1.0x105 cfu/g (cfu - unit-forming colonies) for Candida albicans and Aspergillus brasiliensis. The determination materials and parameters are shown in table 3 [14].

\section{Results and discussions}

In order to assess the stability and compatibility of the product with the plastic container, the parameters of the cosmetic product were monitored both in the tested container and in glass containers, used as controls, in identical conditions. Stability and compatibility testing of product in plastic container is presented in table 4.

The monitoring of the tested product parameters in the plastic container showed that there were no significant changes of the product submitted to test conditions during the assessment. The stability and compatibility tests of the studied cosmetic product in plastic packaging shown stable results, comparable with the organoleptic and physicochemical test results of the control sample stored at room conditions. The appearance of the product tested in plastic container, depending on the temperature variations, is illustrated in figure 1.

There were no changes in appearance, color and fragrance not even in the cycle-test evaluation (table 5). Stability and compatibility testing of product in glass container is presented in table 6 .

The appearance of the product tested in glass container, depending on temperature variations, is illustrated in figure 2.

The chemical composition of the plastic container, declared by the producer (Synthesia Grup, Romania) is: plastic jar $100 \mathrm{~mL}$ PPH Polypropylene homopolymer (Moplen HP648T) and cup PS Styrene homopolymer (Styrolution PS GPPS) with the chemical structure shown in figure 3.

The appearance, smell and color of the plastic container product were monitored under the same conditions; the results are presented in table 7 . The Challenge Test 


\begin{tabular}{|c|c|c|}
\hline Materials & \multicolumn{2}{|c|}{ Parameters } \\
\hline Neutralizer & \multicolumn{2}{|c|}{ Eugon LT 100 liquid broth } \\
\hline Incubation temperature of Petri dishes & \multicolumn{2}{|c|}{$\begin{array}{l}30-35^{\circ} \mathrm{C} / 48-72 \mathrm{~h} \text {, for bacteria } \\
30-35^{\circ} \mathrm{C} / 72 \mathrm{~h} \text {, for Candida albicans } \\
20-25^{\circ} \mathrm{C} / 5 \text { days, for Aspergillus brasiliensis }\end{array}$} \\
\hline Culture media & \multicolumn{2}{|c|}{$\begin{array}{l}\text { Tryptic Soy Agar (TSA), for bacteria } \\
\text { Sabouraud Dextrose Agar culture medium (SDA), for } \\
\text { C. albicans and A. Brasiliensis }\end{array}$} \\
\hline Test strains & \multicolumn{2}{|c|}{$\begin{array}{l}\text { Staphylococcus aureus ATCC } 6538 \\
\text { Escherichia coli ATCC } 8739 \\
\text { Pseudomonas aeruginosa ATCC } 9027 \\
\text { Candida albicans ATCC } 10231 \\
\text { Aspergillus brasilensis ATCC } 16404\end{array}$} \\
\hline \multicolumn{3}{|l|}{ INOCULUM } \\
\hline \multirow{6}{*}{$\begin{array}{l}\text { Quantity of the initial numbers of micro-organisms - N } \\
\text { Quantity of the microorganisms inoculated in the } \\
\text { formulation at time } t_{0}-\mathrm{N}_{0} \\
\mathrm{~N}_{0}=\mathrm{N} / 100\end{array}$} & Microorganism & $\mathrm{Ncfu/g}$ \\
\hline & Staphylococcus aureus & $2.6 \times 10^{7}$ \\
\hline & Escherichia coli & $2.9 \times 10^{1}$ \\
\hline & Pseudomonas aeruginosa & $3.1 \times 10^{7}$ \\
\hline & Candida albicans & $2.1 \times 10^{0}$ \\
\hline & Aspergillus brasiliensis & $2.1 \times 10^{\circ}$ \\
\hline
\end{tabular}

Table 3

CHARACTERISTIC PARAMETERS FOR THE

EVALUATION OF

ANTIMICROBIAL PROTECTION OF THE TESTED COSMETIC PRODUCT

Table 4

STABILITY AND COMPATIBILITY TESTING OF PRODUCT IN PLASTIC CONTAINER

\begin{tabular}{|c|c|c|c|c|c|}
\hline $\begin{array}{c}\text { Hand and body } \\
\text { cream }\end{array}$ & $\begin{array}{c}\text { Initial } \\
\text { evaluation }\end{array}$ & \multicolumn{2}{|l|}{ Evaluation - half of the study program } & \multicolumn{2}{l|}{ Evaluation - end of the study program } \\
\hline Parameters & Caracteristics & $\begin{array}{c}\text { Temperature } \\
\text { variations I }\end{array}$ & $\begin{array}{c}\text { Temperature } \\
\text { variations II }\end{array}$ & $\begin{array}{c}\text { Temperature } \\
\text { variations I }\end{array}$ & $\begin{array}{c}\text { Temperature } \\
\text { variations II }\end{array}$ \\
\hline Appearance & Emulsion & No changes & No changes & No changes & No changes \\
\hline Color & White & No changes & No changes & No changes & No changes \\
\hline Fragrance & Floral scent & No changes & No changes & No changes & No changes \\
\hline $\mathrm{pH}$ & 6.00 & 7.30 & 6.0 & 7.5 & 5.6 \\
\hline Density $\left(\mathrm{g} / \mathrm{cm}^{3}\right)$ & 0.923 & 0.938 & 0.914 & 0.946 & 0.922 \\
\hline
\end{tabular}

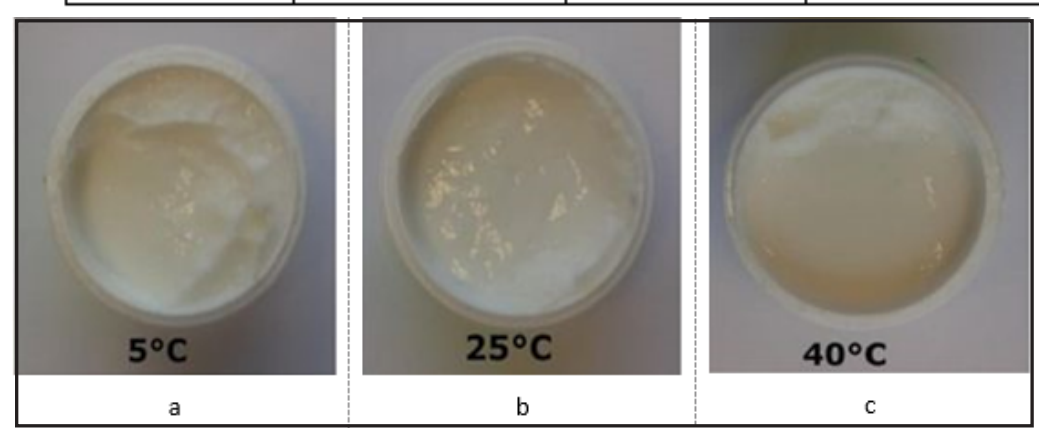

\begin{tabular}{|c|c|c|c|c|}
\hline $\begin{array}{c}\text { Hand and body } \\
\text { cream }\end{array}$ & Initial evaluation & \multicolumn{3}{|c|}{ Cycle test } \\
\hline Parameters & Caracteristics & First series & Second series & Third series \\
\hline Appearance & Emulsion & No changes & No changes & No changes \\
\hline Color & White & No changes & No changes & No changes \\
\hline Fragrance & Floral scent & No changes & No changes & No changes \\
\hline
\end{tabular}

\section{Table 6}

Fig. 1. The appearance of the tested product in plastic container; a Temperature variations $\| 5^{\circ} \mathrm{C}$,

b - Temperature variations $25^{\circ} \mathrm{C}, \mathrm{c}$ - Temperature variations $140^{\circ} \mathrm{C}$

STABILITY AND COMPATIBILITY TESTING OF PRODUCT IN GLASS CONTAINER

\begin{tabular}{|c|c|c|c|c|c|}
\hline $\begin{array}{c}\text { Hand and body } \\
\text { cream }\end{array}$ & Initial evaluation & \multicolumn{2}{|c|}{ Evaluation - half of the study program } & \multicolumn{2}{c|}{ Evaluation - end of the study program } \\
\hline Parameters & Caracteristics & $\begin{array}{c}\text { Temperature } \\
\text { variations I }\end{array}$ & $\begin{array}{c}\text { Temperature } \\
\text { variations II }\end{array}$ & $\begin{array}{c}\text { Temperature } \\
\text { variations I }\end{array}$ & $\begin{array}{c}\text { Temperature } \\
\text { variations II }\end{array}$ \\
\hline Appearance & Emulsion & No changes & No changes & No changes & No changes \\
\hline Color & White & No changes & No changes & No changes & No changes \\
\hline Fragrance & Floral scent & No changes & No changes & No changes & No changes \\
\hline $\mathrm{pH}$ & 6.0 & 7.5 & 5.8 & 7.5 & 6.1 \\
\hline Density $\left(\mathrm{g} / \mathrm{cm}^{3}\right)$ & 0.923 & 0.941 & 0.936 & 0.953 & 0.958 \\
\hline
\end{tabular}

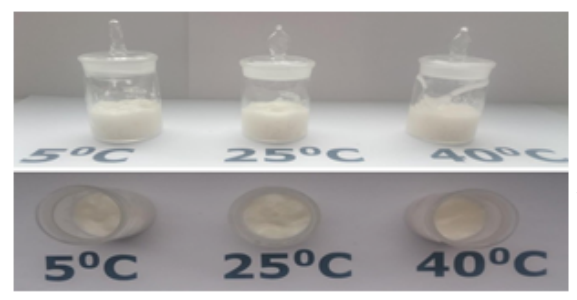

Fig. 2. Appearance of the tested product, depending on temperature variations in glass container

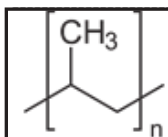

a.
Table 5

STABILITY AND COMPATIBILITY TESTING OF PRODUCT IN THE CYCLE-

TEST EVALUATION
Fig. 3. Chemical structures of the plastic material of the recipient containing compounds; a. - PPH

Polypropylene homopolymer, b. - PS Styrene homopolymer 
Table 7

THE STABILITY ASSESSMENT OF THE PACKAGING

\begin{tabular}{|c|c|c|c|c|c|}
\hline $\begin{array}{c}\text { Hand and } \\
\text { body cream }\end{array}$ & Initial evaluation & \multicolumn{2}{|c|}{$\begin{array}{c}\text { Evaluation - half of the study } \\
\text { program }\end{array}$} & \multicolumn{2}{c|}{$\begin{array}{c}\text { Evaluation - end of the study } \\
\text { program }\end{array}$} \\
\hline Parameters & Caracteristics & $\begin{array}{c}\text { Temperature } \\
\text { variations I }\end{array}$ & $\begin{array}{c}\text { Temperature } \\
\text { variations II }\end{array}$ & $\begin{array}{c}\text { Temperature } \\
\text { variations I }\end{array}$ & $\begin{array}{c}\text { Temperature } \\
\text { variations II }\end{array}$ \\
\hline Appearance & Emulsion & No changes & No changes & No changes & No changes \\
\hline Color & White & No changes & No changes & No changes & No changes \\
\hline Fragrance & $\begin{array}{c}\text { Characteristic for } \\
\text { used ingredients }\end{array}$ & No changes & No changes & No changes & No changes \\
\hline
\end{tabular}

Table 8

THE MICROBIOLOGICAL STABILITY

\begin{tabular}{|c|c|c|c|c|c|c|c|c|c|}
\hline \multirow{3}{*}{ Microorganism } & \multicolumn{9}{|c|}{ Log reduction } \\
\hline & \multirow{2}{*}{$\mathrm{T7}$} & \multicolumn{2}{|c|}{ Criteria } & \multirow{2}{*}{ T14 } & \multicolumn{2}{|c|}{ Criteria } & \multirow{2}{*}{ T28 } & \multicolumn{2}{|c|}{ Criteria } \\
\hline & & $\mathrm{A}$ & $\mathrm{B}$ & & $\mathrm{A}$ & $\mathrm{B}$ & & $\mathrm{A}$ & $\bar{B}$ \\
\hline Staphylococcus aureus & 5.41 & $\geq 3$ & $\mathrm{NP}$ & 5.41 & $\geq 3-N I$ & $\geq 3$ & 5.41 & $\geq 3-\mathrm{NI}$ & $\geq 3-\mathrm{NI}$ \\
\hline Escherichia coli & 5.46 & $\geq 3$ & $\mathrm{NP}$ & 5.46 & $\geq 3-\mathrm{NI}$ & $\geq 3$ & 5.46 & $\geq 3-\mathrm{NI}$ & $\geq 3-\mathrm{NI}$ \\
\hline $\begin{array}{l}\text { Pseudomonas } \\
\text { aeruginosa }\end{array}$ & 5.49 & $\geq 3$ & $\mathrm{NP}$ & 5.49 & $\geq 3-\mathrm{NI}$ & $\geq 3$ & 5.49 & $\geq 3-\mathrm{NI}$ & $\geq 3-\mathrm{NI}$ \\
\hline Candida albicans & 4.32 & $\geq 1$ & $\mathrm{NP}$ & 4.32 & $\geq 1-N I$ & $\geq 1$ & 5.42 & $\geq 1-\mathrm{NI}$ & $\geq 1-\mathrm{NI}$ \\
\hline $\begin{array}{l}\text { Aspergillus } \\
\text { brasiliensis }\end{array}$ & - & - & - & 4.32 & $\geq 0$ & $\geq 0$ & 4.32 & $\geq 0$ & $\geq 0$ \\
\hline
\end{tabular}

confirmed the efficacy of the preservative, the formulation fulfilling the A type criteria [14]. Table 8 presents the stability of the product from the microbiological point of view.

According to SR EN ISO 11930/2012 a deviation of 0.5 log from the established criteria is accepted.

$$
R_{x^{\prime}} \cdot \lg N_{0}-\lg N x
$$

where: $\mathrm{N}_{0}$ - number of the micro-organisms inoculated at time $t_{p} ; \mathrm{N}_{\mathrm{x}}$ - number of surviving micro-organisms at each sampling time $t_{;} \mathrm{NI}$ - no increase in the count from the previous contâct time T7, T14, T28 days; NP - not performed.

Innovation and development in the cosmetics industry determine a direction that promotes health before beauty [15-17].

The products used in cosmetic formulations are constantly diversifying as a result of researches in the field, which combine the healing and prevention of many skin conditions with the use of natural products such as vegetable extracts and essential oils $[9,18,19]$. Research and innovation in this field, as well as in pharmaceutical and environmental fields $[20,21]$ have become necessary, especially nowadays when physical, chemical, and environmental aggressions on the skin cause increasing incidence of skin cancers [22,23].

Testing product attributes that are likely to change while stored, influencing the quality of the cosmetic product, are included in the protocols for cosmetic stability studies. Tests performed in real time or under accelerated conditions must ensure the stability and physical integrity of cosmetic products under appropriate storage and transport conditions, chemical and microbiological stability as well as the compatibility of the contents with the container [24].

Studies on the cosmetics or on their components stability usually include and focus on different accelerated storage conditions under which the samples are kept, in elevated temperature $\left(37,40\right.$ or $\left.45^{\circ} \mathrm{C}\right)$, during different periods of time ( 1 to 3 months), depending on the product type [2429]. In this study, the aspect, color, fragrance, $\mathrm{pH}$ and density were monitored in conditions of temperature variation from 5 to $40^{\circ} \mathrm{C}$, during a period of 2 months.

The tests were carried out in plastic containers (the body and hand cream) which were tested to determine the compatibility of the cream with the material, and in glass containers for control. The stability and compatibility tests of the studied cosmetic product in plastic packaging shown stable results, comparable with the organoleptic and physicochemical test results of the control sample stored at room conditions. The changes in $\mathrm{pH}$ of the cosmetic product in original packaging and glass container after test in temperature variations I $\left(40^{\circ} \mathrm{C}\right.$ ) did not affect the other physical and chemical parameters (aspect, color, smell, density).

The antimicrobial and protection properties of the cosmetic product have also been tested. To ensure the safety of the cosmetic product, microbiological testing is important. The ISO 29621 [30] standard requires that every cosmetic producer has to guarantee that the products they make do not contain microorganisms that may influence the quality of the cosmetic product, that the use of it does not influence negativelly the consumer's health. According to SR EN ISO 1190: 2012 [14], the Challenge Test is used for microbiological tests of newly formulated cosmetic products. In this study the results confirm the microbiological stability of the tested product. In order to keep regulations comming out from above mentioned ISO and EN standards it will be necessary to continue in this research and test the stability of cosmetics products from the point of their odourfor instance by employing electrochemical sensors [31,32].

\section{Conclusions}

The studied product remained stable, regarding the physical and chemical properties, and the microbiological aspect, being compatible with both plastic and glass containers during the test, at storage temperatures that is recommended to be under $40^{\circ} \mathrm{C}$; also, it does not interact with the material of which the container is made.

\section{References}

1.DUNNING T.O.A., Altern. Med., 1, nr. 1, 2013, p. 6.

2.TISSERAND, R., YOUNG, R., Essential oil safety: a guide for health care professional (2nd ed.), Churchill Livingstone, London, 2013. 3.CAVANAGH, H.M., WILKINSON, J.M., Aust. Infection Control, 10, 2005, p. 35.

4.CAVANAGH, H.M., WILKINSON, J. M., Phytother. Res., 16, 2002, p. 301.

5.KOULIVAND, P.H., KHALEGHI GHADIRI, M., GORJI, A., Alternat. Med., 2013, 2013, 681304.

6.KIM, S., KIM, H.J ., YEO, J.S., HONG, S.J ., LEE, J .M., J EON, Y., J. Altern. Complement. Med., 17, 2011, p. 823. 
7.MOON, T., CAVANAGH, H.M.A, WILKINSON, J.M., J. Essent. Oil Res., 19,2007, p. 171.

8.OU, M.C., HSU, T.F., LAI, A.C., LIN, Y.T., LIN, C.C., J. Obstet. Gynaecol. Res, 38, nr. 5, 2012, p. 817.

9.ANDRYS, D., ADASZYNSKA-SKWIRZYNSKA, M, KULPA, D., Nat. Prod. Res., 32, nr. 7, 2018, p. 849.

10.***Regulation of the European Parliament and of the Council (EC) no. 1223/2009 of 30 November 2009 on cosmetic products, Official Journalof the EuropeanUnion, https://ec.europa.eu/health/sites/ health/files/endocrine_disruptors/docs/cosmetic_1223_ 2009 regulation_en.pdf (accesed on 20 December, 2018).

11.MARIES, G.R.E., CHIRA, D., BUNGAU, C., COSTEA, T., MOLDOVAN, L., Mat. Plast., 54, no. 2, 2017, p. 214.

12.CHIRA, D., MARIES, G.R.E., BUNGAU, C., Mat. Plast., 52, no. 4, 2015, p. 572.

13.MARIES, G.R.E., CHIRA, D., BUNGAU, C., Mat. Plast., 52, no. 4, 2015, p. 452.

14. *** ISO 11930:2012, https://webstore.ansi.org/Standards/ISO/ ISO119302012 (accesed on 27 December 2018)

15.CIOCA, G., AGOP, M., POPA, M., BUNGAU, S., BUTUC, I., Rev. Chim.(Bucharest), 68, no. 12, 2017, p. 2925.

16.PAUN, V.A., OCHIUZ, L., HORTOLOMEI, M., CRETEANU, A., STOIERIU, I., GHICIUC, C.M., SERBAN, G.T., ZEGAN, G., CIOCA, G., Mat. Plast., 53, no. 4, 2016, p. 699.

17. PAUN, V.A., POPA, M., DESBRIERES, J ., PEPTU, C.A., DRAGAN, S.V., ZEGAN, G., CIOCA, G., Mat. Plast., 53, no. 4, 2016, p.590.

18.ANDREI, F., ERSILIA, A., TULCAN, C., DRAGOMIRESCU, A., Rec. Nat. Prod., 12, nr. 4, 2018, p. 340.

19. OPREA, O.B., APOSTOL, L., BUNGAU, S., CIOCA, G., SAMUEL, A.D., BADEA, M., GACEU, L., Rev. Chim.(Bucharest), 69, no. 1, 2018, p. 70. 20.CIOCA, G., BACAITA, E.S., AGOP, M., LUPASCU URSULESCU, C., Comput. Math. Methods. Med., 2017, 2017, ID 5748273.

21.OTRISAL, P., MELICHARIK, Z., SVORC, L., BUNGAU, S., VIRCA, I., BARSAN, G., MOSTEANU, D., Mat. Plast., 55, no. 4, 2018, p. 545
22.ENDRES, L., UIVAROSAN, D., TIT, D.M., POP, O., BUNGAU, S., BUHAS, C., Iran. J. Pub. Health, 47, 2018, p. 606.

23.ENDRES, L., TIT, D.M., BUNGAU, S., CIOCA, G., ABDEL-DAIM, M., BUHAS, C., POP, O., SAVA, C., Rev. Chim.(Bucharest), 69, no. 12, 2018, p. 3675 .

24.COSMETICS EUROPE: Guidelines on stability testing of cosmetic products, March 2004, (CTFA)., https://www.cosmeticseurope.eu/files/ 5914/6407/8121/Guidelines_on_Stability_Testing_of_Cosmetics_CECTFA_-_2004.pdf (accesed on $1 \overline{8}$ December 2018)

25.MŌTTEANU, D., BARSAN, G., OTRISAL, P., GIURGIU, L., OANCEA, R., Rev. Chim. (Bucharest), 68, no. 11, 2017, p. 2499.

26.OTRISAL, P., FLORUS, S., BARSAN, G., MOSTEANU, D., Rev. Chim. (Bucharest), 69, no. 2, 2018, p. 300.

27.PETREA, N., GINGHINA, R., PRETORIAN, A., PETRE, R., BARSAN, G., OTRISAL, P., MOSTEANU, D., Rev. Chim. (Bucharest), 69, no. 7, 2018, p. 1640.

28.CAVALU, S., BANICA F., SIMON V., AKIN I., GOLLER G., Int. J. Appl. Ceram. Tec., 11, nr. 2, 2014, p. 402.

29.CAVALU, S., SIMON, V., BANICA, F., OSWALD, I., VANEA, E., AKIN, I., GOLLER, G., Studia UBB Chemia, 56, no. 3, 2011, p. 27.

30.*** ISO 29621:2017, Cosmetics - Microbiology - Guidelines for the risk assessment and identification of microbiologically low-risk products, https://webstore.ansi.org/Standards/ISO/ISO296212017? msclkid = bb13f185fe93163b1c1ladelb720d169\&utm_source= bing\&utm_medium =cpc\&utm_campaign = Campaign $\% 20 \% 231 \& u$ tm $_{-}$ term $=1 S 0 \% 2029621 \& u m_{-}$content=ISO-15K (accesed on 18December 2018).

31.SVORC, L., HASSO, M., SARAKHMAN, O., KIANICKOVA, K., STANKOVIC, M., D., OTRISAL, P., Microchem. J., 142, 2018, p. 297. https://doi.org/10.1016/j.microc.2018.07.007

32.FRITEA, L., BANICA, F., COSTEA, T.O., MOLDOVAN, L., IOVAN, C., CAVALU, S., J. Electroanal. Chem., 830, 2018, p. 63. doi: 10.1016/ j.jelechem.2018.10.015

Manuscript received: 7.12 .2019 